\title{
Supply-demand integrated management model for effective farmer-buyer coordination: case of the Hawaii avocado industry
}

\author{
Jyotsna Krishnakumar ${ }^{1}$, Catherine Chan-Halbrendt ${ }^{1}$, Theodore Radovich ${ }^{2}$, Pauline Sullivan ${ }^{3}$ and Ken Love ${ }^{4}$ \\ ${ }^{1}$ Department of Natural Resources and Environmental Management, University of Hawaii at Manoa, Hawaii 96822, USA; jyotsna@ \\ hawaii.edu; chanhalb@ctahr.hawaii.edu \\ ${ }^{2}$ Tropical Plant and Soil Sciences, University of Hawaii at Manoa, Hawaii 96822,USA; theodore@hawaii.edu \\ ${ }^{3}$ Department of Family \& Consumer Sciences, Texas State University - San Marcos and Department of Textiles and Consumer Sciences, \\ Florida State University; pmsullivan@mailer.fsu.edu \\ ${ }^{4}$ Hawaii Tropical Fruit Growers' Association; kenlove@kona.net
}

\begin{abstract}
The paper presents possible solutions to small farmers in the agricultural sector in a small island setting grappling with challenges of enhancing their local industry and import substitution through a supply-demand chain framework. In 2005, Hawaiian farms produced approximately $363,200 \mathrm{~kg}$ of avocados. However, Hawaiian demand for these fruits required an additional $908,000 \mathrm{~kg}$ of avocados that were supplied through imports. At the same time, it is worth noting; almost $49 \%$ of locally produced avocados did not reach the market. These facts clearly suggest inefficiencies in the local avocado supply chain. Review of the literature on supply chain management suggests a sustainable avocado industry requires an integrated supply and demand chain management system. Hence, a modified conceptual model of supply-chain management called the Supply Demand Integrated Management (SDIM) model is proposed in this paper. Traditional supply chains contain three functional components: supply coordination, physical production and logistic management. In the new model, we propose adding R4D (Research for Development), a public good provided by the government to agricultural industries as an integral part of the supply-demand chain system. It articulates the significance of research and supply chain partnerships between small growers, industry groups, and public agencies. A well-integrated demand/supply chain in the avocado industry allows sharing of vital market information which can contribute to long-term strategic decisions that help local avocado growers increase their competitiveness against foreign imports. It also provides metrics in terms of consumer satisfaction, profitability, competitiveness, self-sufficiency, import substitution and sustainability. The SDIM model as applied to the avocado industry suggests two hypotheses relevant to the current situation. The hypotheses are: (1) There is a lack of coordination between what the farmers are growing and the chefs' (a high-end customer/buyer) preferences; (2) Forming an avocado farmer cooperative will enhance the profitability of local farmers. Survey data was collected from Hawaiian chefs and avocado farmers. Data was analysed using a Duncan multi-range test and a mathematical model, respectively, to test the hypotheses. The test revealed a lack of coordination between what the farmers are growing and buyer preferences. The results from the mathematical model suggested that formation of an avocado marketing cooperative would enhance the profitability of local farmers. Thus, the SDIM framework expands existing body of knowledge about supply chain management and provides useful information to local avocado growers that can help strengthen their supply and demand chain management.
\end{abstract}

Keywords: supply-chain management, farmer cooperative, import substitution, SDIM

\section{Introduction and review of literature}

In 2005, Hawaiian avocado growers supplied approximately $363,200 \mathrm{~kg}$ to the local market, which left a demand deficit of approximately $908,000 \mathrm{~kg}$ that was satisfied by imports (National Agricultural Statistical Service, 2005). Imported avocados have higher prices; almost three to four times the price of local avocados (Chan-Halbrendt et al., 2007). The avocado supply deficit and the higher price for imported avocados clearly indicate potential opportunities for Hawaiian growers to satisfy local avocado demand and substitute imports. Beyond basic product substitution, the Hawaii avocado industry has the ability to supply different varieties of avocados. Hawaiian avocado varieties are versatile and can cater to unique customer tastes, as well as commercial demand for products such as guacamole dips, oil and lotions. Imported varieties, such as Hass, are not as versatile. According to the Hawaii Avocado Association 
there is a lack of available buyer/consumer preference information and little coordination between supply decisions and market demand (Bittenbender et al., 1989). These factors form major constrains to the industry's ability to respond and meet the local demand. Lack of coordination is common in agricultural industry with many small farmers making independent supply decisions in response to conditions in the market place. The situation creates a wide diversity of supply chain management strategies that may cause confusion for buyers (Kydd and Poulton, 2000) thus increasing transaction costs. According to Kydd and Poulton, two important dimensions that an industry with many small farmers must pay attention to in supply chain management are: (1) knowledge of buyer preferences and (2) identify collaborative institutional arrangements, such as forming cooperatives to market their products. Sharing market information among small producers (Chopra and Meindl, 2004) can strengthen their ability to respond to competitive market pressures and their bargaining capacity (Duval and Biere, 1998; Harrison and Storey, 1996; Jang and Klein, 2002).
Literature review provides a foundation for the modified conceptual model of supply-chain management proposed in this study. The model is called the Supply Demand Integrated Model (SDIM) and it partners public and private sectors with agricultural industries to increase their competitive and sustainable position in the market (Figure 1). The key emphasis of this model is the addition of Research for Development (R4D), a necessary concept for making effective supply chain decisions in agriculture, where research is funded by federal grants. This is relevant to an agriculture supply chain comprised of many small farmers who may lack the capacity to conduct research needed to effectively market and distribute their products. R4D encompasses technical or scientific research on agriculture and gathering market intelligence. In this study we are focusing on the latter by finding out consumer preferences and potential coordination strategies to increase revenue and reduce transaction costs. It is integrated into the supply-demand chain, dynamic in nature, providing updated information on the changing market scenario and is implemented using federal funds. SDIM also integrates

\begin{tabular}{|c|c|c|c|c|}
\hline $\begin{array}{l}\text { Supply and } \\
\text { demand } \\
\text { integration }\end{array}$ & $\begin{array}{l}\text { Research for } \\
\text { development (R4D) } \\
\text { activities }\end{array}$ & $\begin{array}{l}\text { Decision } \\
\text { making } \\
\text { components }\end{array}$ & $\begin{array}{l}\text { Specific activities under the } \\
\text { three decision making } \\
\text { components }\end{array}$ & $\begin{array}{l}\text { Outcomes of } \\
\text { adopting this } \\
\text { framework }\end{array}$ \\
\hline \multirow[t]{2}{*}{ SUPPLY } & $\begin{array}{l}\text { Acquiring } \\
\text { knowledge of the } \\
\text { market }\end{array}$ & Strategic & $\begin{array}{l}\text { - Forming alliances such as } \\
\text { cooperative } \\
\text { - Deciding on cooperative size } \\
\text { - Setting prices for produce }\end{array}$ & $\begin{array}{l}\text { - Increases } \\
\text { competitive } \\
\text { advantage }\end{array}$ \\
\hline & $\begin{array}{l}\text { Understanding } \\
\text { industry profile } \\
\text { Exploring buyer } \\
\text { preferences (e.g. }\end{array}$ & & $\begin{array}{l}\text { - Selecting varieties for } \\
\text { production } \\
\text { - Deciding quantity/acres to } \\
\text { produce } \\
\text { - Selecting the market segment } \\
\text { (e.g. chefs) } \\
\text { - Deciding on branding or other } \\
\text { value-added strategies }\end{array}$ & - Enhances outputs \\
\hline DEMAND & $\begin{array}{l}\text { Gathering demand } \\
\text { information } \\
\text { Financial analysis }\end{array}$ & Operational & $\begin{array}{l}\text { Production } \\
\text { - Deciding on planting activities } \\
\text { - Deciding on post harvest } \\
\text { activities } \\
\text { - Making financial management } \\
\text { decisions } \\
\text { Logistics } \\
\text { - Deciding on brand design } \\
\text { - Deciding on packaging } \\
\text { - Arranging for distribution and } \\
\text { mode of transportation }\end{array}$ & $\begin{array}{l}\text { - Increases consumer } \\
\text { satisfaction } \\
\text { - Improves quality } \\
\text { - Improves } \\
\text { response time to } \\
\text { market signals }\end{array}$ \\
\hline
\end{tabular}

Figure 1. Agricultural supply demand integrative management (SDIM) model. 
a demand component and the supply chain flows in a circular direction, different from the conventional linear, unidirectional supply chain model developed by Mentzer (2000). The proposed model also emphasises long-term, strategic decision-making.

\section{Supply demand integrated model}

The SDIM model for agricultural industries, (Figure1) stresses on two key aspects. First, R4D, a contemporary necessary addition that provides vital information and development activities as public goods for the enhancement of the agricultural sector. These services are integrated into supply decisions prior to the onset of production activities which allows local avocado growers to increase their competitive advantage, profitability, improve quality, and satisfy consumer demand (see Figure 1). Second, a traditional supply chain system requires strategic decisions, as well as tactical and operational decisions. Examples of strategic decisions are collaborative efforts such as what type of cooperatives to form and size of the cooperative. Tactical decisions encompass what varieties and how much to grow, which market segments to target their products, and other value added opportunities such as branding. The operational decisions include production activities and logistics. Production activities range from planting through post harvest activities, to financial management decisions. Logistic decisions focus on packaging, and distribution and transportation to markets (Jang and Klein, 2002). Unfortunately there is a dearth of supply chain studies on strategic decision making for small farm enterprises (Hobbs and Young, 2000; Jang and Klein, 2002). The SDIM model proposed in this study recognizes the importance of a supply chain framework that incorporates demand information for small farm enterprises. The model also makes a contribution to existing theory because it emphasizes long-term strategic collaborative arrangements, along with traditional supplychain components, for small agribusinesses such as the Hawaii avocado industry.

Thus the model provides the theoretical framework to confirm two of our hypotheses regarding the industry:

- Hypothesis 1: there is a lack of coordination between what the farmers are growing and the chefs' (a high end customer) buyer) preferences.

- Hypothesis 2: forming an avocado farmer cooperative will enhance the profitability of local farmers.

Since R4D, funded by the government, generates public goods, this study is an illustration of a small-sized agricultural sector linking with land grant university researchers, receiving federal funds to conduct market research to enhance the avocado farmers' competitive position.

\section{Methodology: data collection, sampling and survey instrument}

Two categories of respondents- chefs and Hawaiian avocado farmers were surveyed which yielded two sets of data to analyze in this study. The chef study sample included local chefs from Kona (east side of the Big Island) and Oahu. For the chefs' preference survey, data was collected through a taste-testing event. A total of 43 chefs from Kona and Honolulu, Hawaii participated in the taste testing survey. Kona and Honolulu were selected for two reasons: (1) $80 \%$ of the avocado production in Hawaii is from Kona and (2) Both Kona and Honolulu are the two popular tourist spots with many high-end restaurants. The second survey questionnaire was designed to gather information from local avocado farmers on varieties grown, quantity produced, price received for avocados, and their willingness to form a cooperative. The Hawaii Agricultural Statistics (2005) indicated there was a total of 150 avocado farms in Hawaii in 2005 (National Agricultural Statistics Services, 2005) and of the farmers contacted, 55 agreed to participate and were interviewed.

\section{Procedure}

\section{Hypothesis 1}

Four seasonally available local varieties of avocados- Sharwil, Kahaluu, Malama and Linda (Chan-Halbrendt et al., 2007), along with Hass the imported variety, were provided to the 43 chefs for product preference. These chefs were asked to rate the varieties on a scale of $0-10$ for five characteristics such as ripeness, peeling characteristics, taste, texture and colour. The evaluation scores were compiled and analysed using general linear modelling (ANOVA) and means tested with Duncan's multiple-range test. The significance tests helped in identifying the chefs' preferences and this was then compared with the top five varieties currently being produced.

\section{Hypothesis 2}

Literature review suggested poor marketing strategies would increase transaction costs and reduce revenue to industries. In this study, we hypothesized that forming an avocado marketing cooperative will reduce transaction costs, and generate higher revenue. Since our data also revealed that the majority of avocado farmers $(69.09 \%)$ were willing to form a marketing cooperative it became imperative to find out if there is a higher return in selling through an avocado cooperative. The study used a model developed by Jang and Klein (2002) that simply estimates the returns from 
a cooperative and returns from selling individually, which are then compared. Furthermore, the model was useful as it allowed identification of the optimal cooperative size that gave higher returns (See Equation 1). The mathematical model was based on two assumptions relatively consistent with the current industry status. The assumptions are:

(1) farmers sell only to the wholesaler through the cooperative and (2) each farmer produces the same quantity (Q) to meet the wholesaler and institutional demand (D). The models described below for two case scenarios are based on the above assumptions.

\section{Case scenario one (farmers selling through the cooperative)}

For the purpose of this study, the farmers are producing the quantity to meet the demand $\mathrm{D}$, i.e. $\mathrm{nQ}=\mathrm{D}$ where $\mathrm{n}$ is the number of farmers in the industry (assumption two mentioned above), and selling only to the wholesalers through the cooperative (assumption one mentioned above). In the Jang and Klein (2002) study, Equation 1 below is used to calculate the total revenues of the industry selling partially through the cooperative and partially selling, directly at retail by the farmers individually. Since, in this study, all the farmers are selling to the wholesale industry through a cooperative, Equation 1 was modified to Equation 2 by dropping the second and third component that represented individual sales to calculate the revenue generated solely from the cooperative.

$f(n)=p_{2} D / n+\int_{0}^{Q-D / n} p_{1} x \Phi(x) d x+\int_{Q-D / n}^{\infty} p_{1}(Q-D / n) \Phi(x) d x$

Where:

$\mathrm{f}(\mathrm{n})=$ Revenue generated selling through cooperative/farmer;

$\mathrm{p}_{2}=$ Price received when selling through a cooperative, $\left(\mathrm{p}_{2}<\mathrm{p}_{1}\right) ;$

$\mathrm{D}=$ Demand from wholesalers;

$\mathrm{n}$ = Number of members in a cooperative;

$\mathrm{Q}$ = Production quantity per farmer;

$\mathrm{p}_{1}=$ Price received when selling individually;

$\mathrm{x} \quad=$ Demand faced by farmer selling individually;

$\Phi(x)=$ Probability Density Function (PDF) of $\mathrm{x}$;

$f(n)=p_{2} D / n$

Where:

$\mathrm{f}(\mathrm{n})=$ Revenue generated selling through cooperative/ farmer;

$\mathrm{p}_{2}=$ Price received when selling through a cooperative, $\left(\mathrm{p}_{2}<\mathrm{p}_{1}\right)$;

$\mathrm{D}=$ Demand from wholesalers;

$\mathrm{n}$ = Number of members in a cooperative;

$\mathrm{Q}$ =Production quantity per farmer;

\section{Case scenario two (farmer selling independently)}

In the second case, the farmer only sold individually and not through a cooperative at the retail price $\mathrm{p}_{1}$, where $\mathrm{p}_{1}>\mathrm{p}_{2}$ (the wholesale price), to meet the total demand $\mathrm{D}$. These prices are set as per the current industry scenario where wholesale selling price is lower than retail. Since farmers sell individually, theoretically they face a stochastic demand. To account for this, a probability density function of the total demand was incorporated. Equation 3 was used for calculating the second case scenario where the first component of Equation 3 is the total revenue received by farmers selling individually and the second component of Equation 3 is the adjustment of revenues due to the stochastic nature of market demand.

$f(0)=+\int_{0}^{Q} p_{1} x \Phi(x) d x+\int_{Q}^{\infty} p_{1} Q \Phi(x) d x$

Where:

$f(0)=$ Revenue generated per farmer selling independently;

$\mathrm{Q}=$ Production quantity per farmer;

$\mathrm{p}_{1}=$ Price received when selling individually;

$\Phi(x)=$ Probability Density Function (PDF) of this $\mathrm{x}$;

$\mathrm{x}=$ Demand faced by farmer selling individually;

$\mathrm{Q}, \mathrm{D}, \mathrm{x}, \mathrm{n}, \mathrm{p}_{1}$ and $\mathrm{p}_{2}$ are known. In using Equation 3 to calculate revenues, the probability distribution $(\Phi(x))$ had to be determined. Forty-five years of historical demand data for avocados in Hawaii was collected and the probability distribution was determined using MATLAB software. The results showed the probability distribution for Hawaii avocado demand is normally distributed.

\section{Results of hypotheses testing}

\section{Hypothesis 1}

The results of the taste testing are presented in Table 1. The mean scores along with the results of the Duncan tests for each of the taste testing characteristics are statistically differentiated by the alphabets $\mathrm{A}, \mathrm{B}$ or $\mathrm{C}$, which indicate a significant preference for local varieties of Kahaluu, Malama and Linda over Sharwil and the imported Hass. Duncan tests for avocado product attributes such as ripeness, taste and texture indicate Kahaluu, Malama and Linda are similar and they are preferred over Sharwil and imported Hass. Duncan tests for peeling characteristics indicate that all the four local varieties are similar and significantly preferred over imported Hass. In the case of colour, Linda is similar to Kahaluu, Malama and Sharwil and Sharwil is similar to Linda and imported Hass. Sharwil is the most produced local variety that was promoted extensively by the industry 
Table 1. Results of taste testing of the avocado characteristics by varieties and overall score of each variety by local (Kona and Honolulu) chefs.

\begin{tabular}{|c|c|c|c|c|c|c|c|c|c|c|c|}
\hline $\begin{array}{l}\mathrm{Pr}>\mathrm{F} \text { by variety * } \\
\text { location }\end{array}$ & \multicolumn{2}{|c|}{$\begin{array}{l}\text { Ripeness } \\
(P>0.05)\end{array}$} & \multicolumn{2}{|c|}{$\begin{array}{l}\text { Peeling } \\
\text { characteristics } \\
(P<0.05)\end{array}$} & \multicolumn{2}{|c|}{$\begin{array}{l}\text { Taste } \\
(P>0.05)\end{array}$} & \multicolumn{2}{|c|}{$\begin{array}{l}\text { Texture } \\
(P>0.05)\end{array}$} & \multicolumn{2}{|c|}{$\begin{array}{l}\text { Color } \\
(P>0.05)\end{array}$} & $\begin{array}{l}\mathrm{Pr}>\mathrm{F} \text { by variety * } \\
\text { location }\end{array}$ \\
\hline $\begin{array}{l}\mathrm{Pr}>\mathrm{F} \text { by variety } \\
\text { alone }\end{array}$ & \multicolumn{2}{|c|}{$\begin{array}{l}\text { Ripeness } \\
(P<0.01)\end{array}$} & \multicolumn{2}{|c|}{$\begin{array}{l}\text { Peeling } \\
\text { characteristics } \\
(P<0.01)\end{array}$} & \multicolumn{2}{|c|}{$\begin{array}{l}\text { Taste } \\
(P<0.05)\end{array}$} & \multicolumn{2}{|c|}{$\begin{array}{l}\text { Texture } \\
(P<0.01)\end{array}$} & \multicolumn{2}{|c|}{$\begin{array}{l}\text { Colour } \\
(P<0.05)\end{array}$} & $\begin{array}{l}\text { Overall average } \\
\text { score }(P<0.0001)\end{array}$ \\
\hline Avocado varieties & MS* & $+/ \mathrm{SE}^{*}$ & MS & $+/-S E$ & MS & $+/-\mathrm{SE}$ & MS & $+/-\mathrm{SE}$ & MS & $+/-\mathrm{SE}$ & MS \\
\hline Kahaluu & $8.30^{\mathrm{A}}$ & 0.29 & $8.50^{\mathrm{A}}$ & 0.23 & $7.43^{\mathrm{A}}$ & 0.42 & $7.87^{\mathrm{A}}$ & 0.33 & $8.60^{\mathrm{A}}$ & 0.20 & $8.17^{\mathrm{A}}$ \\
\hline Malama & $8.61^{\mathrm{A}}$ & 0.23 & $8.23^{\mathrm{A}}$ & 0.32 & $7.43^{\mathrm{A}}$ & 0.39 & $8.13^{A}$ & 0.29 & $8.40^{\mathrm{A}}$ & 0.23 & $8.08^{\mathrm{A}}$ \\
\hline Linda & $8.22^{\mathrm{A}}$ & 0.24 & $8.09^{A}$ & 0.26 & $7.47^{\mathrm{A}}$ & 0.33 & $8.08^{\mathrm{A}}$ & 0.34 & $8.33^{B, A}$ & 0.38 & $8.13^{\mathrm{A}}$ \\
\hline Sharwil & $7.30^{\mathrm{B}}$ & 0.35 & $7.41^{\mathrm{A}}$ & 0.32 & $6.43^{\mathrm{B}}$ & 0.41 & $7.04^{B}$ & 0.31 & $7.81^{B, C}$ & 0.29 & $7.17^{B}$ \\
\hline Hass & $7.30^{\mathrm{B}}$ & 0.26 & $6.71^{\mathrm{B}}$ & 0.48 & $6.13^{B}$ & 0.39 & $6.73^{B}$ & 0.35 & $7.34^{C}$ & 0.34 & $6.78^{B}$ \\
\hline
\end{tabular}

*MS: Mean Score; SE: Standard Error.

Mean with same letter $(A, B, C)$ not significantly different from each other at $\alpha=0.05$.

in the 1980s for export purposes due to its similarity to Hass in characteristics (Bittenbender et al., 1989). Only in terms of peeling characteristics Sharwil showed similarity with all the other three local varieties that buyers preferred over Sharwil. The overall average means score in order of preference are: Kahaluu at (8.17) followed by Linda (8.13), Malama (8.08), Sharwil (7.17) and imported Hass (6.78). Thus the statistical test showed that the local varieties Kahaluu, Linda and Malama are preferred over Sharwil and imported Hass, which is currently being imported to Hawaii in large volumes. There were also no significant differences in preferences for varieties by location (Kona or Oahu) except for peeling characteristics which showed $P<0.05$.

Following testing of the chefs' preferences, the total production of the top five varieties obtained from the producer survey was calculated. Results revealed that Sharwil has the highest volume of production with $45 \%$, followed by Malama with $21 \%$, Yamagata with $11 \%$, Murashige with $3 \%$ and Hass with 9\% (Chan-Halbrendt et al., 2007). When this was compared with the results from the taste tests (Table 1), it indicated a mismatch between the current production level by varieties and the buyers' (the chefs) preferences for varieties thereby confirming Hypothesis 1 . As mentioned earlier, one of the key dimensions in a successful smallsized agribusiness is knowledge of buyer preference (Kydd and Poulton, 2000). Confirming Hypothesis 1 showed that the local avocado industry does not know the buyers' preference. This clearly supports the importance of R4D in the SDIM framework involving public-private partnership with federal funding to provide vital market information to small-sized agribusiness that otherwise cannot afford to conduct the market research. Our survey data also shows that the majority of the farmers are willing to switch to grow varieties consumers/buyers prefer (Chan-Halbrendt et al., 2007).

\section{Hypothesis 2}

The revenues generated by selling through the cooperative versus selling individually were calculated. Average annual demand (D) of avocados for five years, 2002-2006, was $1,035,665 \mathrm{~kg}$; average price received from wholesalers, $\mathrm{p}_{2}$ was $\$ 1.9 / \mathrm{kg}$; average price received when individually sold, $\mathrm{p}_{1}$ was $\$ 2.3 / \mathrm{kg}$. If $\mathrm{n}=103$ (this is equivalent to $69.09 \%$ of 150 farmers who said they are willing to join a cooperative), then the quantity produced and sold by each farmer is $10,055 \mathrm{~kg}(\mathrm{Q}=\mathrm{D} / \mathrm{n}=1,035,665 / 103)$. The amount matches closely with our survey data where the majority have an average farm size of about 10 acres and each acre produces approximately $908 \mathrm{~kg}$ of avocados. The revenues calculated using Equation 2 and Equation 3 is for per year, per farmer and in terms of production units. The size of the farm is assumed to be the same for all farmers. This is a reasonable assumption since majority of farmers according to the study's data have an average farm size of 10 acres as mentioned previously (Chan-Halbrendt et al., 2007).

Total revenue per farmer was calculated for various cooperative membership sizes for comparison with selling individually. Figure 2 illustrates the revenue trends when sold individually at retail price, versus when sold through 
a cooperative at lower wholesale price (the lower price was used as this is what the farmers selling to wholesalers currently receive even though it biases against selling through the cooperative; however the profit margin might be higher since the cooperative costs are lower due to economies of scale) for different farmer membership sizes. At a cooperative size of 103, which is the number of farms willing to form a cooperative, the revenue generated by the cooperative (rectangular dots) is higher than selling individually (diamond dots) until the size of the cooperative reaches a size of 125 farmers. Beyond this point selling through cooperatives draws in lower revenue at the wholesale price than selling individually at retail price. As per the equation for calculating the cooperative's revenue $(f$ $\left.(n)=p_{2} D / n_{1}\right)$ since $\mathrm{D}$ does not change (in other words we are calculating for the current demand situation), as more farmers join the coop (as $n$ increases), automatically the revenue decreases. However, wholesale cooperatives have an advantage of having market power and can demand a higher price. A simulation was run with the wholesale price increased (by a conservative 10 cents more than the current wholesale price) with the results revealing that with the entire current population of avocado farmers in the State (150) joining a cooperative (triangular dots) receives higher revenue than farmers selling individually. One small caveat of this result is the assumption that each Hawaiian avocado farmer is producing the same amount to meet the demand through the cooperative. However, as mentioned previously the majority of farmers in the industry have the capacity to expand their avocado production to meet this demand if they are not currently at that level. And, taking into account the increased bargaining capacity of farmers in a cooperative, from the results, Hypothesis 2 can be confirmed.

\section{Conclusions}

Analysis confirms Hypothesis 1 that there exists poor supply-demand coordination in the local avocado industry. The study shows that market information is crucial since majority of the Hawaii avocado farmers do not produce the varieties consumers/buyers prefer. Majority of the interviewed avocado farmers are willing to adopt collaborative supply chain management arrangement such as forming a marketing cooperative. Results supported Hypothesis 2, forming an avocado farmer cooperative will enhance the profitability of local farmers. Marketing cooperatives provide farmers with a higher return for avocados than selling individually. Pertinent information from this study coupled with cooperative efforts could help decrease the current production wastage of $49 \%$ and help Hawaiian producers to increase competitiveness against imports. Implications from this study assert the relevance of adopting the SDIM model for small-scale agribusiness. To begin with, a greater reliance on R4D (Research for Development), integral to SDIM model, will encourage and assist farmers to work closely with research institutions, universities and extension agents to gather crucial market information such as customer preferences and meet the demand preferences. Adopting this model enables farmers to cater effectively to different market segments, bargain for higher prices, and create stable income. It thus enhances coordination between supply decisions and market demand that is currently lacking in the industry.

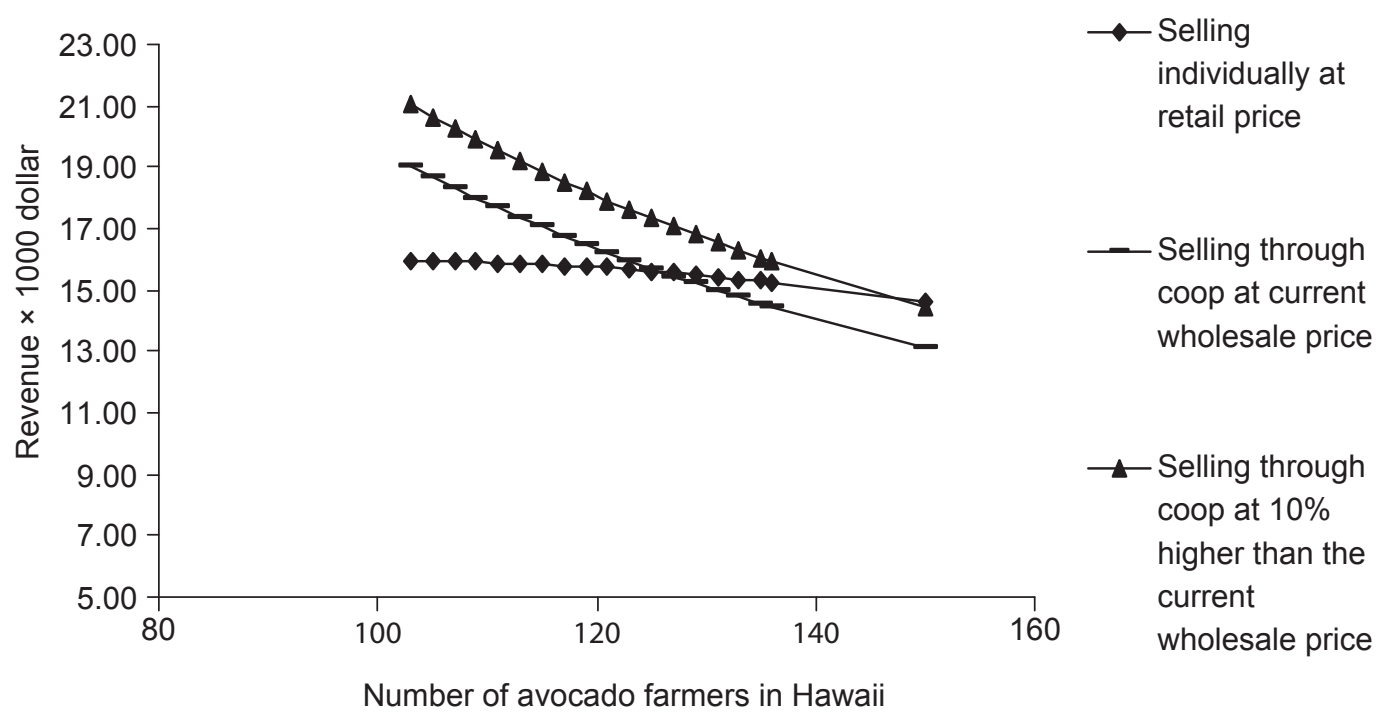

Figure 2. Estimated revenue trend per farmer sold individually vs. through cooperative revenue at two different price levels. 
Therefore, it is recommended that avocado varieties that are most preferred by customers must be promoted. State support should be provided to organize a farmer-owned marketing cooperative whose benefits have been shown by this study. Policies that support local farming, provision of incentives to local farmers to continue farming such as the New Agricultural Land Bill must be encouraged and State branding programs must be made easily available to farmers and effectively implemented in order to promote local products. Branding increases customer awareness, improve coordination and enhance sales, which would benefit the industry. Last but not least, the SDIM model provides a useful tool in identifying weak supply chain links for an industry with many small farmers. Once the information gaps for strategic decisions have been identified based upon the SDIM model and acted upon, publicly supported research demonstrates how providing quality information helps industry participants work together, increase effective supply chain management, and improve their competitive position in order to stave off product imports.

\section{References}

Bittenbender, C.H., N. Kefford and K.G Robrhach, 1989. Agricultural industry Analysis: The status, potential, and problems of Hawaiian crops, Avocado Industry Analysis.

Chan-Halbrendt, C., J. Krishnakumar, K. Love and P. Sullivan, 2007. Hawaii Avocado Industry Analysis: Part I: Supply Focus. University of Hawaii, College of Tropical Agriculture and Human Resources.Economic Issues. Nov. 2007, EI-12.

Chopra, S. and P. Meindl, 2004. Supply Chain Management, Strategy, Planning and Operation, Prentice Hall.

Duval, B. and A. Biere, 1998. Grain Producers' Attitudes to New Forms of supply-chain coordination. International Food and Agribusiness Review, 1(2): 179-193.

Harrison, A. and J. Storey, 1996. New wave manufacturing strategies-operational, organizational and human dimensions. International Journal of Operations and Production management, 16(2): 63-76.

Hobbs, J. and L.M. Young, 2000. Closer Vertical Co-ordination in Agri-Food Supply Chains: A Conceptual Framework and Some Preliminary Evidence. Supply Chain Management: An International Journal, 5(3): 131-142.

Jang, W. and C.M. Klein, 2002. Supply Chain Models for Small Agricultural Enterprises, Conference Proceedings, http://citeseer. ist.psu.edu/cache/papers/cs/26387/http:zSzzSzfie.engrng.pitt. eduzSziie2002zSzproceedingszSzierczSzpaperszSz2175.pdf/ supply-chain-models-for.pdf (Web Link accessed- 01-17-2009).
Kydd, J.G. and C. Poulton, 2000. Agricultural liberalisation, commercialisation and the market access problem. Part II of Killick, Kydd and Poulton, The Rural Poor and the Wider Economy: the Problem of Market Access, background paper for IFAD Rural Poverty 2000 report, Rome.

Mentzer, T.J., 2000. Supply Chain Management, Sage Publications, California, pp. 8-9.

National Agricultural Statistics Service, Statistics of Hawaii Agriculture, 2004, 2005. http://www.nass.usda.gov/hi/stats/t_ of_c.htm. 
